\title{
KELAYAKAN PENGEMBANGAN MODEL INTEGRASI HIJAUAN-KELAPA
}

\author{
AGNITJE RUMAMBI \\ FAKULTAS PETERNAKAN UNIVERSITAS SAM RATULANGI \\ Email/HP: agnitjerumambi @ymail.com/o85242429297
}

\begin{abstract}
ABSTRAK
Penduduk miskin di Indonesia diperkirakan sebesar 19\% dari populasi penduduk. Salah satu ciri penduduk miskin adalah kekurangan gizi meliputi protein, zat besi, vitamin A, seng dan yodium. Pemerintah Indonesia menyikapi masalah kemiskinan dan kelaparan dengan memperkuat ketahanan pangan melalui peningkatan produksi pangan, diverifikasi pangan serta memperbaiki distribusi pangan. Tujuan kajian ini adalah untuk mengetahui kelayakan pengembangan model integrasi hijauan-kelapa. Dasar pemikiran produktivitas kelapa secara monokultur adalah rendah, sehingga perlu pemanfaatan lahan dibawah tegakan kelapa dengan pengembangan integrasi hijauan-kelapa. Masalah yang perlu ditangani dalam pengembangan model hijauan-kelapa adalah mengenai (1) kelayakan agronomis seperti pemilihan jenis hijauan yang sesuai dengan iklim mikro di bawah kelapa (2) kelayakan teknis menyangkut manajemen hijauan-kelapa, (3) kelayakan ekonomis dan (4) kelayakan lingkungan model hijauan-kelapa. Kesimpulan, Pengembangan hijauan dibawah kelapa memiliki beberapa keuntungan dan kerugian. Namun resiko kerugian dapat dikurangi dengan melakukan analisis kelayakan agronomis, teknis, ekonomi dan lingkungan.
\end{abstract}

Kata kunci: kelayakan, integrasi, hijauan, kelapa

\section{DEVELOPMENT WORTHINESS OF FORAGE-COCONUT INTEGRATION MODEL}

\begin{abstract}
$19 \%$ of the population in Indonesia lives below the official poverty line. One of the poverty characteristics is poor nutrients i.e. protein, ferrum, vitamin A, zinc, and jodium. The Indonesia government addresses problems of poverty and starvation by strengthening food supply, increasing food production, food diversification, and improving food distribution. This study aims to determine the development worthiness of forage- system coconut integration model. The idea of coconut productivity in monoculture system is low, so land usage under coconut with development of forage-coconut integration is essential. Problems in the development of forage-coconut system, consists of: (1) agronomic worthiness such as types of forage selection which suitable to micro climate under coconut; (2) technical worthiness concern on forage-coconut management; (3) economy worthiness; and (4) worthiness of forage-coconut environment model. It can be concluded that forge development under coconut has advantages and disadvantages. However, risk of disadvantages could be decreased by agronomy worthiness analysis, technical, economy and environment.
\end{abstract}

Keywords: worthiness, integration, forage, coconut

\section{PENDAHULUAN}

Kemiskinan dan kelaparan merupakan salah satu masalah global yang dihadapi oleh negara-negara di dunia. Penduduk miskin dunia mencapai $17 \%$ dari populasi penduduk (Von Braun et al. 2005). Penduduk miskin di Indonesia diperkirakan sebesar 19\% dari populasi penduduk. Salah satu ciri penduduk miskin adalah kekurangan gizi meliputi protein, zat besi, vitamin A, seng dan yodium. Pemerintah Indonesia menyikapi masalah kemiskinan dan kelaparan dengan memperkuat ketahanan pangan melalui peningkatan produksi pan- gan, diverifikasi pangan serta memperbaiki distribusi pangan.

Ternak merupakan sumber utama pangan dengan produk utama daging, susu dan telur. Permintaan daging diperkirakan meningkat $57 \%$ pada periode $1997-$ 2020 sebagai akibat meningkatnya konsumsi daging per kapita dari $37 \mathrm{~kg}$ pada tahun 1997 menjadi sekitar $60 \mathrm{~kg}$ pada tahun 2020 (Gambar 1). Dampak peningkatan permintaan daging adalah meningkatnya permintaan pakan. Hal ini tergambar dari permintaan pakan dari tanaman biji-bijian rata-rata $2,5 \%$ per tahun (Rosegrant et al. 2001). 


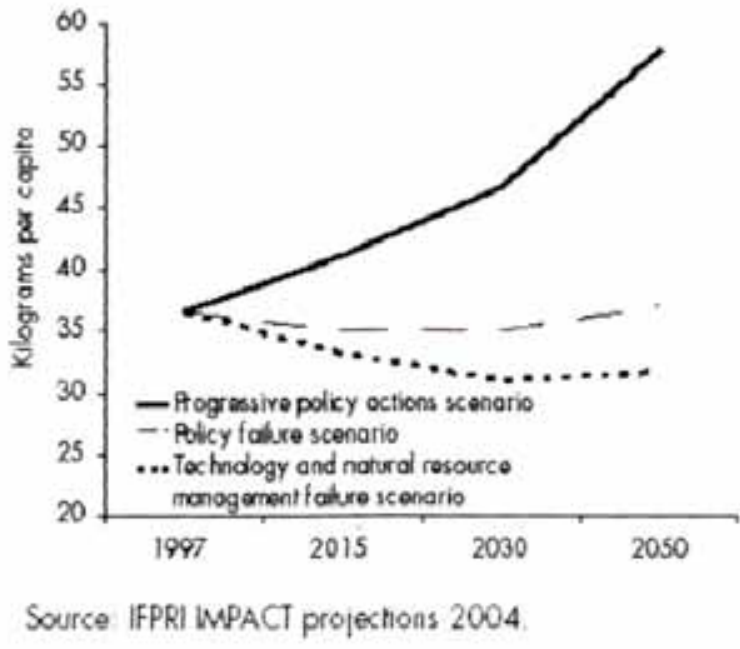

Gambar 1. Permintaan daging dunia per kapita.

Peningkatan konsumsi daging berimplikasi terjadinya peningkatan populasi dan produksi ternak yang diikuti oleh peningkatan permintaan pakan. Salah satu masalah utama yang dihadapi dalam peningkatan produksi pakan di Indonesia adalah ketersediaan lahan produksi. Lahan-lahan yang ada umumnya diprioritaskan untuk pengembangan tanaman pangan perkebunan dan holtikultura. Peluang perluasan areal tanaman masih tersedia dalam bentuk tanaman sela di antara tanaman perkebunan terutama kelapa. Secara tradisional, ternak telah dimanfaatkan sebagai 'penyapu' atau pembersih, mempertahankan rumput dan gulma tetap pendek, mencegah kompetisi hara dan air yang berlebihan dengan kelapa serta mempermudah proses panen kelapa. Untuk meningkatkan daya tampung ternak, di beberapa daerah penanaman rumput dan legum dilakukan di bawah kelapa. Masalah yang perlu ditangani dalam pengembangan model pastura-kelapa adalah mengenai (1) kelayakan agronomis seperti pemilihan jenis hijauan yang sesuai dengan iklim mikro di bawah kelapa (2) kelayakan teknis menyangkut manajemen pastura-kelapa, (3) kelayakan ekonomis dan (4) kelayakan lingkungan model hijauankelapa. Berdasarkan pemikiran diatas maka perlu dikaji kelayakan pengembangan model integrasi hijauan-kelapa diareal pertanaman kelapa.

\section{DASAR PEMIKIRAN}

Produktivitas aktual perkebunan kelapa rakyat masih sangat rendah karena diusahakan secara tradisional. Pertanaman kelapa monokultur menyediakan lahan dan ruang yang luas diatas tanah (Mahmud. 2008). Pemanfaatan lahan dibawah tegakan kelapa dengan pengembangan model integrasi hijauan-kelapa merupakan salah satu upaya meningkatkan produktivitas lahan dan meningkatkan pendapatan petani peternak.

\section{PEMBAHASAN}

Kelayakan pengembangan model hijauan-kelapa harus memenuhi beberapa kriteria berikut (Nelliat, Bavappa dan Nair, 1974):

1. Layak agronomis (agronomical feasibility) yaitu model yang diterapkan harus dapat menjamin peningkatan produksi tanaman pokok dan tanaman sela;

2. Layak teknis (technical feasibility) yaitu dapat diterapkan sesuai kemampuan sosial budaya petani;

3. Layak ekonomi (economical feasibility) yaitu model yang diterapkan harus memberi nilai tambah ekonomi;

4. Layak lingkungan (environmental feasitability) yaitu model yang diterapkan menunjang kelestarian lingkungan atau tidak menyebabkan kerusakan atau ancaman lingkungan.

1. Kelayakan Agronomis

0.1. Kesesuaian lahan dan iklim mikro

a. Nair (1983) mengemukakan bahwa perakaran efektif berada pada radius $2 \mathrm{~m}$ dan terkonsentrasi pada kedalaman 1,5 meter. Lahan dibawah kelapa yang dapat dimanfaatkan tanaman kelapa monokultural tidak efektif dalam pemanfaatan lahan.

b. Kanopi tanaman kelapa hanya menempati 30-40 \% ruang di atas tanah di antara kanopi dan permukaan tanah. Dengan demikian, 60-70 \% dapat ditanami tanaman lain.

c. Liyanage (1985) mengemukakan bahwa 55 \% radiasi matahari tersedia bagi tanaman sela. Radiasi matahari bervariasi menurut umur dan tinggi tanaman kelapa. Model hubungan umur kelapa dan persentase transmisi radiasi dibawah kelapa yang dikembangkan Nelliat et al (1974) menunjukkan bahwa pada umur kurang dari 5 tahun transmisi radiasi tergolong baik, umur 5-20 tahun transmisi rendah, dan transmisi meningkat pada umur diatas 20 tahun. Dengan demikian, pada tanaman kelapa berumur 5-20 tahun harus dikembangkan hijauan yang toleran terhadap naungan. Kualitas radiasi di bawah kelapa tidak sama dengan di tempat terbuka. Cahaya biru dan merah berkurang dibanding cahya hijau dan merah panjang (far red). Proporsi cahaya merah dan merah panjang/jauh di tempat terbuka 1-20 sementara dibawah kelapa 1.03. Penurunan rasio merah/merah jauh dapat menyebabkan morfogenesis atau perubahan morfologi tanaman seperti pemanjangan dan penghambatan pertunasan dan percabangan.

d. Pada sistem usaha tani polikultur kompetisi antara tanaman pokok dan tanaman sela terhadap air dan unsur hara adalah hal yang umum terjadi. Kompetisi tidak akan terjadi atau minimal apabila air dan unsur hara tersedia cukup bagi kedua tanaman. 
0.2. Pemilihan Jenis Hijauan

Jenis hijauan yang ditanam dibawah kelapa harus memiliki beberapa kriteria berikut (Akuba, Sangeroki, dan Litouw, 1998)

a. Hijauan tidak lebih tinggi dari tanaman pokok kelapa selama periode pertumbuhannya dan sistem perakaran serta tajuknya menempati horizon tanah dan ruang diatas tanah yang berbeda.

b. Hijauan tidak merupakan tanaman inang bagi hama dan penyakit yang berbahaya bagi tanaman pokok. Tanaman sela tidak lebih peka dari tanaman pokok terhadap serangan hama dan penyakit.

c. Pengelolaan tanaman hijauan di bawah kelapa tidak menyebabkan kerusakan pada tanaman pokok.

d. Hijauan yang dipilih untuk dijadikan tanaman sela diantara kelapa harus sesuai diusahakan pada ketinggian 0-500 $\mathrm{m}$ diatas permukaan laut, kisaran curah hujan yang diperlukan 1500-3500 mm per tahun dengan bulan kering ( $<130 \mathrm{~mm} /$ bulan) tidak lebih dari 3 bulan berturut-turut, toleran terhadap kerapatan radiasi 50-200 $\mathrm{Wm}^{-2}$, suhu rata-rata $25^{-}$ $27 \mathrm{C}$ dan kelembaban relative $80 \%$.

e. Beberapa hijauan yang berpeluang diusahakan dibawah kelapa disajikan pada Tabel 1.

Tabel 1. Tanaman hijauan di bawah kelapa

\begin{tabular}{lclllll}
\hline \multicolumn{1}{c}{ Jenis pastura } & $\begin{array}{r}\text { Radiasi } \\
(\mathrm{Wm}-2)\end{array}$ & $\begin{array}{l}\text { Curah hujan } \\
(\mathrm{mm} / \text { tahun })\end{array}$ & Suhu C & $\mathrm{RH}(\%)$ & $\begin{array}{r}\text { Tinggi } \\
\text { tempat } \\
\text { (m dpl) }\end{array}$ \\
\hline Arachis pintoi & $60-120$ & $1500-2500$ & $20-30$ & $85-95$ & $0-500$ \\
A.repens & $60-200$ & $1500-2500$ & $20-30$ & $70-90$ & $0-500$ \\
Desmodium sp & $78-300$ & $1500-2500$ & $20-30$ & $70-90$ & $0-500$ \\
Paspalum conjugatum & $78-300$ & $1500-2500$ & $20-30$ & $70-90$ & $0-500$ \\
P. notatum & $78-300$ & $1500-2500$ & $20-30$ & $70-90$ & $0-500$ \\
Axonophus compressus & $78-300$ & $1500-2500$ & $20-30$ & $70-90$ & $0-500$ \\
Glirisidia sepium & $50-300$ & $1500-2500$ & $24-35$ & $70-90$ & $0-700$ \\
Stylosnthes sp & $50-300$ & $1500-2500$ & $25-30$ & $70-90$ & $0-700$ \\
Setaria sp & $100-300$ & $1500-2500$ & $25-30$ & $70-90$ & $0-500$ \\
\hline
\end{tabular}

Sumber : Akuba et al,1998.

f. Besarnya presentase radiasi yang ditransmisikan sampai di bawah kelapa menjadi pertimbangan utama pemilihan jenis hijauan di bawah kelapa. Hal ini disebabkan karena kemampuan tanaman mengakumulasi cadangan karbohidrat sangat menurun pada keadaaan ternaung. Jadi, spesies yang menyimpan biomassa di akar, rhisoma atau stolon lebih toleran terhadap naungan disbanding spesies yang tegak yang memaksimumkan produksi daun (Wilson, 1991). Beberapa spesies hijauan yang tahan naungan disajikan pada Tabel 2. Tanaman dengan toleransi terhadap naungan tinggi sebaiknya ditanam pada saat kelapa umur 5-20 tahun, toleransi sedang pada umur kelapa lebih dari dari 20 tahun dan toleransi rendah pada tanaman kelapa umur kurang dari 5 tahun.
Tabel 2,. Hijauan toleran terhadap naungan

\begin{tabular}{|c|c|c|}
\hline $\begin{array}{l}\text { Tingkat } \\
\text { toleransi } \\
\text { terhadap } \\
\text { naungan }\end{array}$ & Rumput-rumputan & Legum \\
\hline Tinggi & $\begin{array}{l}\text { Axonopus compressus } \\
\text { Brachiaria miliformis } \\
\text { Ischaemum aristatum } \\
\text { Ottochloa nodosa } \\
\text { Paspalum conjugatum } \\
\text { Stenotaphrum secundatum }\end{array}$ & $\begin{array}{l}\text { Calopogonium caeruleum } \\
\text { Desmodium heterophyllum } \\
\text { D.ovalifolium } \\
\text { Flemingia congesta } \\
\text { Mimosa pudica }\end{array}$ \\
\hline Medium & $\begin{array}{l}\text { Brachiaria bizanta } \\
\text { B. decumbens } \\
\text { B. humidicola } \\
\text { Digitaria setivalva } \\
\text { Imperata cylindrical } \\
\text { Panicum maximum } \\
\text { Pennisetum purpureum } \\
\text { Setaria sphacelata } \\
\text { Uruchloa mozambicensis }\end{array}$ & $\begin{array}{l}\text { Arachis pintoi } \\
\text { Calopogonium mucunoides } \\
\text { Centrosema pubescens } \\
\text { Desmodium triflorum } \\
\text { D.intortum } \\
\text { D.canum } \\
\text { Pueraria phaseoloides } \\
\text { Leucaena leucocephala } \\
\text { Neonotonia wightii } \\
\text { Vigna luteola }\end{array}$ \\
\hline Rendah & $\begin{array}{l}\text { Brachiaria mutica } \\
\text { Cynodon plectostachycus } \\
\text { Digitaria decumbens } \\
\text { D.Pentzii }\end{array}$ & $\begin{array}{l}\text { Stylosanthes Hamate } \\
\text { S.Guianensis } \\
\text { Zornia Diphylla } \\
\text { Macroptilium atropurpureum }\end{array}$ \\
\hline
\end{tabular}

Sumber : Reynolds, 1995

g. Iniguez dan Sanchez (1991) menyarankan untuk tanaman kelapa umur 3-6 tahun dengan tingkat transmisi radiasi $30-50 \%$ tanaman pastura yang cocok adalah Arachis sp, Desmodium ovalifolium, Paspalum notatum, P. wettsteinii, dan Axonopus compressus. MacFarlane et al. (1994) menyarankan beberapa spesies yang cocok dikembangkan dibawah kelapa yaitu Brachiaria humidicola, B Decumbens, Stenotaphrum secundatum, A.pintoi, A.repens, A. glabrata, dan Desmodium heterophyllum.

o.3. Kelayakan Teknis.

Kelayakan teknis dalam pengembangan model pastura kelapa memiliki bebrapa persyaratan, sebagai berikut : a. Model yang dikembangkan sesuai dengan kondisi sosial budaya petani/peternak. Kondisi sosial budaya yang perlu diperhatikan adalah tingkat keterampilan, pendidikan dan adat istiadat. Model yang mempertimbangkan keadaan sosial budaya petani akan cepat diterima oleh masyarakat dan berkelanjutan.

b. Model pasture-kelapa sederhana sehingga mudah secara praktis untuk diterapkan dilapangan. Kombinasi tanaman yang terlalu banyak akan menyulitkan dalam pengelolaan tanaman. Sebaiknya dua tanaman sela pasture cukup.

c. Input teknologi yang diperlukan tersedia di daerah pengembangan seperti bahan tanaman dan sarana produksi serta pengolahan. Pemilihan jenis hijauan perlu disesuaikan dengan kebutuhan tingkat pengelolaan dari pastura. Tingkat pengelolaan beberapa pastura disajikan pada Tabel 3 .

d. Pengembangan model pastura-kelapa memerlukan kelembagaan usaha tani yang kuat agar usaha tani dapat dilaksanakan secara berkelanjutan. 
Tabel 3. Tingkat Pengelolaan beberapa hijauan

\begin{tabular}{|c|c|c|}
\hline \multicolumn{3}{|c|}{ Tingkat Pengelolaan } \\
\hline Rendah & Sedang & Tinggi \\
\hline \multicolumn{3}{|c|}{ Rumput-rumputan } \\
\hline $\begin{array}{l}\text { A. compressus } \\
\text { S. dimidiatum } \\
\text { S. secundatum } \\
\text { L. aristatum }\end{array}$ & $\begin{array}{l}\text { B. humidicola } \\
\text { B. brizantha } \\
\text { B. decumbens }\end{array}$ & $\begin{array}{l}\text { B. miliformis } \\
\text { B. mutica } \\
\text { P. maximum }\end{array}$ \\
\hline \multicolumn{3}{|c|}{ Legum } \\
\hline $\begin{array}{l}\text { D. heteropyllum } \\
\text { A. vaginalis } \\
\text { T. labialis }\end{array}$ & $\begin{array}{l}\text { P. phaseoloides } \\
\text { C. pubescens } \\
\text { L. leucocephala }\end{array}$ & $\begin{array}{l}\text { S. guinanensis } \\
\text { M. atropurpureum }\end{array}$ \\
\hline
\end{tabular}

\section{o.4. Kelayakan Ekonomi}

Pengembangan pastura dibawah kelapa haruslah memberikan keuntungan ekonomi bagi petani peternak. Keuntungan akan diperoleh apabila terjadi peningkatan produksi tanaman pokok, peningkatan hasil pastura yang berakibat pada peningkatan bobot badan ternak yang diusahakan serta biaya input yang rendah.

Reynolds (1995) melaporkan bahwa pengembangan pastura dibawah kelapa pada tahap awal menekan produksi akibat tekanan hara oleh pastura. Apabila kadar air tanah dan hara diberikan cukup untuk memenuhi kebutuhan pastura dan kelapa maka produksi kelapa tidak terpengaruh bahkan meningkat, apabila stocking rate sesuai. Pada tanah-tanah berat dengan tingkat pemadatan yang tinggi pengembangan hijauan meningkatkan hasil kelapa. Fakor-faktor yang mempengaruhi produksi kelapa pada sistem pastura kelapa yaitu tingkat kadar air, pemupukan, jenis hijaun, grazing system dan stocking rate, legume yang digunakan dalam pakan, pengolahan tanah, dan pengendalian gulma. Peningkatan produksi sebesar $20 \%$ terjadi pada sistem pastura-kelapa yang dipupuk intensif.

Reynolds (1981) melaporkan terdapat peningkatan berat ternak sapi yang diusahakan di bawah kelapa dengan jenis hijauan Centrosema baik dipupuk maupun tidak pada stocking rate 1,7-1,8 Peningkatan bobot hidup berkisar antara $0,17 \mathrm{~kg}$ per hari pada areal yang dipupuk dan 0,49 kg per hari pada areal yang dipupuk. Pada pastura alami dibawah kelapa bobot hidup ternak sapi lebih tinggi dari pastura yang diintroduksi. Meningkatnya stocking rate dari 1,5 menjadi 3,5 per ha menyebabkan penurunan bobot hidup yang nyata. Secara umum, pengembangan pastura meningkatkan produktifitas ternak dan kelapa.

\subsection{Kelayakan Lingkungan}

Pengembangan hijauan di bawah kelapa haruslah layak lingkungan dalam pengertian tidak menyebabkan peningkatan erosi, menyebabkan keragaman hayati, mencemari lingkungan, dan meningkatkan eksploitasi hama dan penyakit. Oleh karena itu pemilihan jenis hijauan dan pengelolaan harus memperhatikan aspekaspek lingkungan.
1. Keuntungan dan Kerugian Pengembangan Hijauan di Bawah Kelapa

\subsection{Keuntungan}

Beberapa keuntungan pengembangan hijauan dibawah kelapa meliputi :

a. Peningkatan dan diverifikasi sumber pendapatan petani/peternak (Darwis, 1998)

b. Miningkatkan hasil dan produksi pangan

c. Meningkatkan stabilitas usaha tani kelapa melalui diverifikasi produk kelapa

d. Meningkatkan produksi kelapa melalui perbaikan teknik budidaya pemanfaatan lahan dibawah kelapa

e. Mengurangi penggunaan pestisida yang berarti mencegah pencemaran lingkungan

f. Mengurangi biaya produksi kelapa

g. Membuka lapangan kerja dan kesempatan kerja

h. Berpeluang mengurangi bencana seperti angin ribut, hama dan penyakit, banjir dan erosi

i. Meningkatkan kesuburan tanah

j. Penggunaan sumberdaya lahan dan modal lebih efisien

k. Meningkatkan produksi ternak.

\subsection{Kerugian}

Beberapa kemungkinan pengaruh buruk dari sistem hijauan-kelapa adalah sebagi berikut :

a. Kompetisi air dan hara antara hijauan dan kelapa

b. Pengembangan tanaman sela hijauan kemungkinan tidak ekonomis apabila keliru memilih jenis tanaman yang tidak sesuai dibawah kelapa.

c. Tanaman sela mungkin dapat menarik hama dan penyakit yang berbahaya bagi kelapa

d. Menanam lebih dari satu tanaman menghendaki input sarana produksi yang lebih banyak

e. Pengolahan tanah dapat menyebabkan kerusakan akar kelapa

f. Karakteristik tumbuh dari tanaman sela dapat menyulitkan teknik budidaya

g. Ternak dapat menyebabkan kerusakan tanaman kelapa terutama tanaman muda

h. Pengembangan hijauan dibawah kelapa menghendaki ketrampilan yang lebih baik dari petani terutama dalam hal pemeliharaan ternak

i. Kotoran ternak dapat menjadi sarang bagi hama kumbang kelapa Oryctes rhinoceros $L$.

Pengembangan hijauan dibawah kelapa memiliki beberapa keuntungan dan kerugian. Resiko kerugian dapat dikurangi dengan melakukan analisis kelayakan agronomis, teknis, ekonomi dan lingkungan. Beberapa hasil penelitian menunjukkan model hijauan-kelapa layak agronomis, teknis, ekonomi dan lingkungan.

Dari hasil kajian ini masih diperlukan penelitian dalam menunjang pengembangan model hijauan dibawah kelapa yang efisien di suatu daerah. Kegiatan- 
kegiatan yang perlu dilakukan meliputi (1) penentuan jenis hijauan yang sesuai berdasarkan kondisi iklim dan tingkat manajemen yang diperlukan; (2) penentuan pola usahatani model hjauan-kelapa yang efisien; dan (3) evaluasi dampak ekonomi, lingkungan dan keragaman hayati pengembangan hijauan dibawah kelapa.

\section{DAFTAR PUSTAKA}

Akuba, R. H., A. Sangeroki dan F. Litouw, 1998. Rancangan system usahatani berbasis kelapa di Sulawesi Utara. Seminar Regional Hasil Penelitian Kelapa dan Palma. Manado 25-26 Februari 1998.

Darwis, S. N. 1998. Status of intercropping on coconut lands in Indonesia. Proc. Workshop on Incropping and Intergrazing in Coconut Areas. Colombo, 7-11 September 1988.

Iniguez, l.C. and M.D. Sanchez. 1991 Integrated tree cropping and small ruminants production system. Proc. Workshop on Res. Meth., Medan North Sumatera, Indonesia.329p. USAID.

Joachim von Braun, mark W. Rosegrant, rajul Pandya-Lorch, March J. Cohen, Sarah A. Cline, Mary Ashby Brown, and Maria Soledad Bos. 2005. New Risks and Oppurtunities fo Food Security. Scenario Alayses for 2015 and 2050. International Food Policy Research Institute. Washington, DC, USA. February 2005.
Lyanagem L.V.K. 1985. Rationale for Intercropping. Coconut Bulletin 2(2):31-35.

MacFarlane, D. C., B.F.Mullen, T.R. Evans, C.K. MacDonalds, and R.Eberhard. 1994. Vanuatu improvement project. Final Tech.Report. Port Villa Vanuatu.

Mahmud Z, 2008. Modernisasi Usaha Tani Kelapa Rakyat. Pengembangan Inovasi Pertanian 1(4), 2008: 274-287. Bogor.

Nair, P.K.R. 1983. Agroforestry with coconut and other tropical plantation crops. In. Palnt Research and Agroforestry (ed. P.a.Huxley), ICRAF, Nairobi, Kenya. 617p.

Nelliat, E. V., K.V. Bavappa and P.V.R Nair. 1974. Multi-storey cropping, a new dimension in multiple cropping for coconut plantations. World Crops 26(6):262-266

Reynolds, S.G. 1981. Grazing trials under coconut in Western Samoa. Trop. Grasslands, 5(1)3-10.

Reynolds, S.G. 1995. Pasture-Cattle-Coconut System. FAO. Bangkok

Rosegrant, M.W., M.S. Paisner, S.Meijer, Julie Witcover. 2001. Global Food Projections to 2020. IFPRI.

Wilson, J.R. 1991. Ecophysiogical constraints to production and nutritive guality of pastures under tree crops. In Proc. Of Int. Livestock-Treee Cropping Workshop (ed ajudin) Serdang, Malaysia, p39-54. 